\title{
Cloning and functional characterization of a new Ski homolog, Fussel-18, specifically expressed in neuronal tissues
}

\author{
Stephanie Arndt ${ }^{1}$, Ina Poser ${ }^{1}$, Thomas Schubert ${ }^{1}$, Markus Moser ${ }^{2}$ and \\ Anja-Katrin Bosserhoff ${ }^{1}$ \\ ${ }^{1}$ University of Regensburg Medical School, Regensburg, Germany and ${ }^{2}$ Max-Planck-Institute of Biochemistry, \\ Martinsried, Germany
}

\begin{abstract}
The Sloan Kettering Virus (Ski) family of nuclear oncoproteins represses transforming growth factor- $\beta$ (TGF- $\beta$ ) signaling through inhibition of transcriptional activity of Smad proteins. Here, we report the discovery of a new functional Smad suppressing element on chromosome 18 (Fussel-18). Fussel-18 encodes for a protein of 297 amino acids sharing characteristic structural features, significant homology and similar genomic organization with the homolog Ski family members, Ski and Ski-related novel sequence (Sno). In contrast to Ski and Sno, which are ubiquitously expressed in human tissues, in situ hybridization, RT-PCR, Western blot and immunohistochemistry revealed a highly specific expression pattern for Fussel-18 in neuronal tissues, especially in the cerebellum, the spinal cord and dorsal root ganglia, during both embryogenesis and adult stage. Functionally, we determined interaction of Fussel-18 with Smad 2 and Smad 3 together with an inhibitory activity on TGF- $\beta$ signaling. Fussel-18 is the first example of a Smad-binding protein with a highly restricted expression pattern within the nervous system.
\end{abstract}

Laboratory Investigation (2005) 85, 1330-1341. doi:10.1038/labinvest.3700344; published online 3 October 2005

Keywords: cerebellum; transforming growth factor; inhibitor; ski family; Smad; signaling

Transforming growth factor- $\beta$ (TGF- $\beta$ ) signaling from the cell membrane to the nucleus is mediated by the Smad family of proteins regulating cell growth, cell proliferation, differentiation and apoptosis. ${ }^{1,2}$ In the absence of TGF- $\beta$, Smad proteins are distributed in both the nucleus and cytoplasm. ${ }^{3,4}$ After stimulation by TGF- $\beta$, Smad 2 and Smad3 become phosphorylated by the activated TGF- $\beta$ receptors and oligomerize with Smad4., ${ }^{3,5}$ Subsequently, these Smad complexes accumulate in the nucleus where they interact with other transcription factors, ${ }^{6}$ bind to DNA and activate transcription of TGF- $\beta$ target genes. Among the negative regulators of Smad function as Smad-7, Sloan Kettering Virus (Ski) etc, and Ski-related novel sequence (Sno) are two highly conserved members of the Ski family of proto-oncoproteins. High levels of Ski or SnoN are associated with many types of human cancer cells. ${ }^{7,8}$ Ski or SnoN antagonize TGF- $\beta$ signaling through

Correspondence: Dr A-K Bosserhoff, PhD, Institute of Pathology, University of Regensburg, Franz-Josef-Strauss-Allee 11, Regensburg D-93053, Germany.

E-mail: anja.bosserhoff@klinik.uni-regensburg.de

Received 3 May 2005; revised and accepted 14 July 2005; published online 3 October 2005 direct interaction with Smad4, Smad2 or Smad3. ${ }^{9-12}$ A 8-bp palindromic sequence (GTCTAGAC) was initially identified to be a high-affinity binding site for Ski. ${ }^{13}$ However, Ski cannot bind to this sequence directly. Instead, Ski binds to this site along with Smad3 and Smad $4{ }^{13}$ leading to the hypothesis that Ski may bind to the GTCTAGAC sequence indirectly through interaction with Smad4 or Smad3. Ski and SnoN interaction with Smad4 is constitutive, whereas Ski and SnoN interact with Smad2 and Smad3 in a TGF- $\beta$-dependent manner. ${ }^{14-17}$ Ski may also inhibit TGF- $\beta$-induced transcriptional responses by competing with Smad2 and Smad3 binding to Smad4. ${ }^{18,19}$ In addition, Ski has also been reported to inhibit TGF- $\beta$ signaling by suppressing Smad2 phosphorylation by the receptor. ${ }^{20}$ The mechanism of Ski-mediated repression of TGF- $\beta$ signaling has been primarily attributed to transcriptional modulation, through recruitment of the nuclear corepressor (N-CoR) and histone deacetylase complex (HDAC) as well as interference of Smad-mediated binding to the transcriptional coactivator, p300/CBP. ${ }^{5}$

Here, we describe the identification of a novel human gene, functional Smad suppressing element on chromosome 18 (fussel-18), encoding for a Ski 
homolog protein, which is characterized by a ski homolog domain and a SAND domain. The new member shares $30.8 \%$ amino-acid identity and $53 \%$ cDNA sequence identity with Ski. Fussel-18 encodes for a protein of about $30 \mathrm{kDa}$ and 297 amino acids, respectively. Interestingly, in contrast to the broad expression patterns previously determined for the other members of the ski gene family, fussel-18 is specifically expressed in the nervous system.

\section{Materials and methods}

\section{Blast Searches, Homology Searches}

The human genome (NCBI), EST and IMAGE gene banks were searched for Ski homologous proteins using the BL̄AST algorithm. Comparisons of DNA and amino-acid homology, construction of molecular phylogenetic trees and Kyte-Doolittle-Blots were performed using the DNAman software (Lynnon Biosoft, USA).

\section{Cell Lines and Cell Culture Conditions}

Three cell lines were used: 293T cell line (ATCC CRL-1573), a glioblastoma cell line HTZ-17 (gift from U Bogdahn, University of Regensburg, Germany) and the melanoma cell line Mel Im (generous gift from Dr Johnson, University of Munich, Germany). All were maintained in DMEM supplemented with penicillin $(400 \mathrm{U} / \mathrm{ml})$, streptomycine $(50 \mu \mathrm{g} / \mathrm{ml})$, L-glutamine $(300 \mu \mathrm{g} / \mathrm{ml})$ and $10 \%$ fetal calf serum (Sigma, Deisenhofen, Germany) and split 1:5 ratio every 3 days.

\section{Semiquantitative PCR Analysis}

To perform semiquantitative PCR, RNAs were obtained from Clontech (Heidelberg, Germany) and Ambion (Austin, USA). First strand cDNA was synthesized using $2 \mu \mathrm{g}$ of total RNA, $1 \mu \mathrm{g}$ random primer (Pharmacia, Freiburg, Germany), $4 \mu \mathrm{l} 5 \times$ first strand buffer (Invitrogen, Groningen, The Netherlands), $2 \mu \mathrm{l}$ of $0.1 \mathrm{M}$ DTT, $1 \mu \mathrm{l}$ of $10 \mathrm{mM}$ dNTPs and DEPC-water. The reaction mixture was incubated for $10 \mathrm{~min}$ at $70^{\circ} \mathrm{C}, 200 \mathrm{U}$ of Superscript II reverse transcriptase (Invitrogen) were added and RNA was transcribed for $1 \mathrm{~h}$ at $37^{\circ} \mathrm{C}$. Reverse transcriptase was inactivated at $70^{\circ} \mathrm{C}$ for $10 \mathrm{~min}$ and the RNA was degraded by digestion with $1 \mu \mathrm{l}$ RNase A $(10 \mathrm{mg} / \mathrm{ml})$ at $37^{\circ} \mathrm{C}$ for $30 \mathrm{~min}$.

\section{Expression Analysis}

To screen for mRNA expression semiquantitative PCR was performed (PTC-200, Biozym, Hess. Oldendorf, Germany) using the following gene-specific primers and $\beta$-actin primers for standardization (hFussel-18 for 380: $5^{\prime}$-gcaagtcgttcctgggcgaaa-3'; hFussel-18 rev 623: $5^{\prime}$-gagttgaagttggctgcgtc-3'; $\beta$ - actin for 723: $5^{\prime}$-ctacgtcgccctggacttcgagc-3'; $\beta$-actin rev 1107: $5^{\prime}$-gatggagccgccgatccacacgg- $3^{\prime}$ ). The PCR reaction was performed in a $50 \mu \mathrm{l}$ reaction volume containing $5 \mu \mathrm{l} 10 \times$ Taq-puffer, $1 \mu \mathrm{l}$ of cDNA, $1 \mu \mathrm{l}$ of each primer $(20 \mu \mathrm{M}), 0.5 \mu \mathrm{l}$ of dNTPs $(10 \mu \mathrm{M}), 0.5 \mathrm{U}$ of Taq polymerase and $41 \mu \mathrm{l}$ of water. The following PCR program was used: 32 cycles of $1 \mathrm{~min}$ at $94^{\circ} \mathrm{C}$, $45 \mathrm{~s}$ at $64^{\circ} \mathrm{C}$ and $1 \mathrm{~min}$ at $72^{\circ} \mathrm{C}$, final extension of $2 \mathrm{~min}$ at $72^{\circ} \mathrm{C}$. PCR products were separated on a $1.5 \%$ agarose gel, stained with ethidium bromide and documented. All PCR reactions were repeated at least three times.

For further experiments we isolated RNA from human cerebellum tissue using the RNeasy kit (Qiagen, Hilden, Germany). Approximately $0.4 \mathrm{~cm}^{3}$ tissue were homogenized in lysis buffer by sonification. RNA was purified from lysis buffer with RNeasy spin columns. 1/10 of the RNA was used for each RT-PCR.

\section{Whole Mount In Situ Hybridization}

Whole mount in situ hybridization was performed essentially as described. ${ }^{21}$ Radioactive in situ hybridization of 33P-labeled cRNA probes to paraffinembedded embryo sections was described in detail previously. ${ }^{22}$ As a probe, a 522-bp fragment obtained from the human fussel $18 \mathrm{cDNA}$ were amplified by PCR using following primers fussel18 fw 101: $5^{\prime} \mathrm{cca}$ acc tca aac cca acc ag3' and fussel18 rev 623: 5'gag ttg aag ttg gct gcg tc $3^{\prime}$ and subcloned into pCRIITOPO. Owing to the high homology between the human and mouse fussel $18 \mathrm{cDNAs}$, this probe was also used for hybridizations of murine tissues.

\section{Western Blot Analysis}

Approximately $0.4 \mathrm{~cm}^{3}$ tissue were homogenized by sonification in $200 \mu$ l RIPA-buffer (Roche) and incubated for $15 \mathrm{~min}$ at $4^{\circ} \mathrm{C}$. Insoluble fragments were removed by centrifugation at $13000 \mathrm{rpm}$ for $10 \mathrm{~min}$ and the supernatant lysate was stored at $-20^{\circ} \mathrm{C}$. RIPA-cell lysate was loaded and separated on $10 \%$ SDS-PAGE and subsequently blotted onto PVDF membrane. After blocking for $1 \mathrm{~h}$ with $3 \%$ BSA/PBS the membrane was incubated for $16 \mathrm{~h}$ with a primary antibody (polyclonal anti-Fussel-18 rabbit antiserum (1:200) against the c-terminal peptide generated by BioGenes $\mathrm{GmbH}$, Berlin), $\beta$-actin (Sigma, 1:2500). For peptide-blockade $5 \mu \mathrm{g} / \mathrm{ml}$ peptide of Fussel-18 was given to the primary antibody. Then the membrane was washed three times in PBS, incubated for $1 \mathrm{~h}$ with an alkaline phosphatecoupled secondary antibody (Chemicon) and then washed again. Finally, immunoreactions were visualized by NBT/BCIP (Zytomed) staining.

\section{Immunohistochemistry}

Paraffin-embedded serial sections of human adult cerebellum were screened for Fussel-18 protein 
expression and additional for glial or neuronal expression with different markers by immunohistochemistry. The tissues were deparaffinized, rehydrated and subsequently incubated with primary rabbit anti-Fussel-18 antibody (BioGenes $\mathrm{GmbH}$, Berlin, Germany, 1:20) or pretreated with citrate buffer, pH6 for $1 \mathrm{~h}$ at $90^{\circ} \mathrm{C}$ and incubated with primary mouse anti-Synaptophysin- (Progen Biotechnik GmbH, Heidelberg, Germany, 1/50), antiGFAP- (Dako, Germany, 1/50) or antineurofilament antibody (DAKO, 1/50) overnight at $4^{\circ} \mathrm{C}$. The secondary antibody (biotin-labeled anti-rabbit/antimouse, DAKO) was incubated for $30 \mathrm{~min}$ at room temperature, followed by incubation with streptavidin-POD (DAKO) for $30 \mathrm{~min}$. Antibody binding was visualized using AEC-solution (DAKO). Finally, the tissues were counterstained by hemalaun solution (DAKO). The evaluation of the staining was performed semiquantitatively by light microscopy.

\section{Immunofluorescence}

In all, $5 \times 10^{5}$ HTZ-17 glioblastoma cells were grown on a four-well chamber slide for 1 day, washed with PBS and fixed with $4 \%$ paraformaldehyde for $15 \mathrm{~min}$, incubated for $5 \mathrm{~min}$ with $0.1 \%$ Triton-X100 (Sigma) for permeabilization of the cell membrane, washed again and covered with blocking solution (PBS/1\% BSA) for $1 \mathrm{~h}$. Thereafter, cells were incubated with Fussel-18 antibody (1:20) for $1 \mathrm{~h}$ by room temperature. After washing the cells, they were incubated with secondary antibody (Cy3conjugated Affinpure goat anti-rabbit IgG F (ab) antibody (1:10), Jackson Immunoresearch, USA) for $1 \mathrm{~h}$ followed by washing with PBS. After mounting with Hard Set Mounting Medium with DAPI (Vectashield, H-1500) images were collected by fluorescence microscopy.

\section{Subcellular Proteome Extraction}

In all, $3 \times 10^{5} 293 \mathrm{~T}$ cells were seeded into each well of a six-well plate and transfected with $0.5 \mu \mathrm{g}$ plasmid DNA (pCMX-PL2-Flag-fussel-18) for $24 \mathrm{~h}$. Protein isolation for membrane, cytoplasm and nuclear fraction was performed using the ProteoExtract Subcellular Proteome Extraction Kit from Calbiochem as described by the manufacturer (Calbiochem, EMD Biosciences, Darmstadt, Germany).

\section{Co-Immunoprecipitation}

In all, $3 \times 10^{5}$ Mel Im melanoma cells were seeded into each well of a six-well plate and transfected with $0.5 \mu \mathrm{g}$ plasmid DNA (pcDNA3-FLAG-c-Ski, pCMX-PL2-Flag-Fussel-18, pcDNA3-Smad2 or pcDNA3-Smad3) for $24 \mathrm{~h}$. These cells were used because transfection of these cells is well established in our lab. For co-immunoprecipitation cell lysates of Mel Im cells were incubated with $5 \mu \mathrm{g}$ of anti-Flag M2 monoclonal antibody (Sigma) with shaking at $4^{\circ} \mathrm{C}$ overnight. Then $20 \mu \mathrm{l}$ protein G Sepharose 4 Fast Flow (Amersham, Biosciences) was added for $1 \mathrm{~h}$, pelleted, washed three times with PBS, resuspended in Laemmli's buffer, heated at $95^{\circ} \mathrm{C}$ for $10 \mathrm{~min}$ and separated on $10 \%$ SDS-PAGE. Smad2 and Smad3 were detected by Western blotting using the anti-Smad3 (H-2) antibody from Santa Cruz Biotechnology which also recognizes Smad 1 and Smad2.

\section{Transfection and Reporter Gene Assay}

For transient transfections $2-3 \times 10^{5} 293 \mathrm{~T}$ cells were seeded into each well of a six-well plate and transfected with $0.5 \mu \mathrm{g}$ plasmid DNA using the lipofectamine plus method (Gibco) according to the manufacturer's instructions. The cells were lysed $24 \mathrm{~h}$ after transfection and the luciferase activity in the lysate was quantified by a luminometric assay (Promega Corp., Madison, USA). Transfection efficiency was normalized according to renilla luciferase activity by cotransfecting $0.1 \mu \mathrm{g}$ of the plasmid pRL-TK (Promega). All transfections were repeated at least four times. For transient transfection the plasmids (CAGA) $)_{9}$-Luc (generous gift from Steven Dooley, University of Mannheim, Germany), pcDNA3-FLAG-c-Ski or pCMX-PL2-FlagFussel-18 were cotransfected for $4 \mathrm{~h}$, followed by washing the cells with PBS and stimulation with $10 \mathrm{ng}$ of TGF- $\beta-3$ for $20 \mathrm{~h}$. All reporter gene assays were repeated at least four times.

\section{Results}

\section{Identification of a New Member of the Ski Gene Family}

BLAST searches of the human EST and IMAGE databases identified several clones with high homology to the ski cDNA sequence. These clones were

\footnotetext{
Figure 1 Comparison of human ski, sno and fussel-18 sequences. (a) Complete cDNA sequence of fussel-18. The start codon is marked in bold, the stop codon in bold and italic. (b) Sequence alignment of human Ski, Sno and Fussel-18 amino-acid sequences. Conserved amino acids are in white letters on a black background. The underlined $\mathrm{Cys}_{2}-\mathrm{His}_{2}$ zinc binding module is a part of the SAND domain and conserved in all members of the Ski/Sno family. The peptide used to generate a polyclonal rabbit anti Fussel 18 antiserum is framed. (c) Homology between Ski, Sno and Fussel-18 on protein level shown as a homology tree. The tree was constructed using the program DNAman based on the alignment of the complete coding region. The length of each horizontal line is proportional to the degree of protein sequence divergence. (d) Schematic diagram of the structural organization. The conserved Ski homolog regions of Ski, Sno and Fussel-18 are shown. The amino-acid homology of this area is indicated in \%.
} 
allocated to the following three groups: The first group comprised partial or full-length ski cDNA clones, the second group partial or full-length sno
cDNA clones. The third group was assembled to a novel homolog gene and designated fussel-18. The accession numbers are listed in Table 1.

1 atggettcca gtccgctgcc agggcccaac gacatcctgc tggegtcgec gtcgagcgec

61 ttccagcccg acacgctgag ccagccgcgg ccagggcacg ccaacctcaa acccaaccag

121 gtgggccagg tgatcctcta cggcattccc atcgtgtcgt tggtgatcga cgggcaagag

181 cgcctgtgcc tggcgcagat ctccaacact ctgctcaaga acttcagcta caacgagatc

241 cacaaccgtc gcgtggcact gggcatcacg tgtgtgcagt gcacgccggt gcaactggag

301 atcctgcggc gtgccggggc catgcccatc tcatcgcgce gctgcggcat gatcaccaaa

361 cgcgaggccg agcgtctgtg caagtcgttc ctgggcgaaa acaggccgcc caagctgcca

421 gacaatttcg ccttcgacgt gtcacacgag tgcgcctggg gctgccgcgg cagcttcatt

481 cccgcgcgct acaacagctc gcgcgccaag tgcatcaaat gcagctactg caacatgtac

541 ttctcgccca acaagttcat tttccactcc caccgcacgc ccgacgccaa gtacactcag

601 ccagacgcag ccaacttcaa ctcgtggcge cgtcatctca agctcaccga caagagtccc

661 caggacgagc tggtcttcgc ctgggaggac gtcaaggcca tgttcaacgg cggcagccgc

721 aagcgcgcac tgccccagce gggcgcgcac cccgcctgcc acccgctcag ctctataaga

781 acaaggagca tagctttttc atcacagact ctgatgcttc tggaggagat ttttggagag

841 aaagatcagg aggattatat gcgaataaat gaggacaaca tttggttatg a

b $s k i$

sno

fussel 18

Consensus

ski

sno

fussel 18

Consensus

ski

sno

fussel_18

Consensus

ski

sno

fussel 18

Consensus

ski

sno

fusse1_18

Consens̄us

ski

sno

fusse1_18

Consensus

ski

sno

fussel_18

Consensus

ski

sno

fussel_18
Consensus

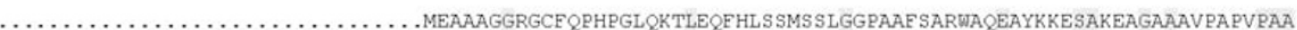

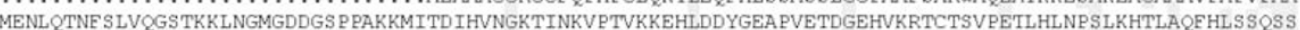
MENLQTNE SLVQGSTKKLNGMGDDGS P PAKKMITD IHVNGKTINKVPTVKKEHLDDYGEA.PVETDGEHVKRTCTSVPETLHLNPSLKHTLAQEHLSSQSS

g
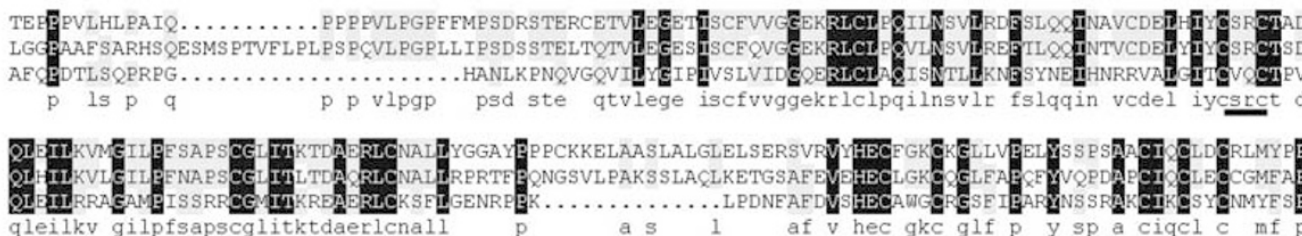

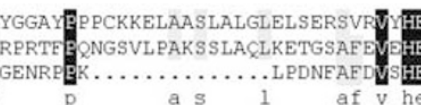
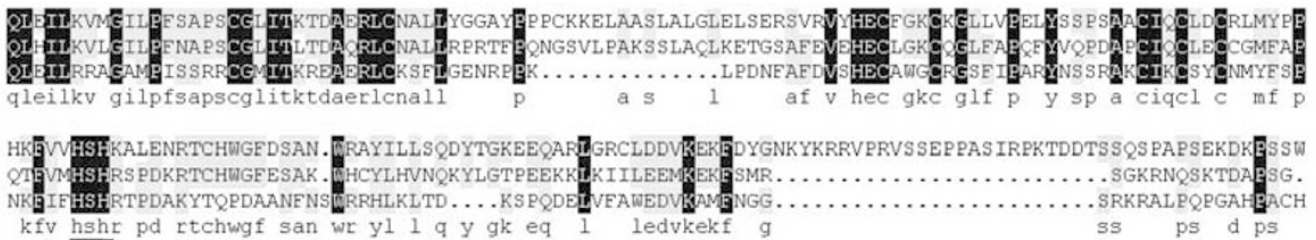

RAYILLSQDYTGKEEQAPI

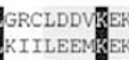

FTYGNKYKRRVPRVSSEPPASIRPKTDDTSSOSPAPSEKDKESSW

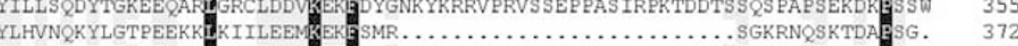

LRTLAGS SNKSLGCVHPRQRLSAFRPWSPAVSASEKELS PHL PALIRDSE YSYKSEETAVAPIVATAP PAQQKVVSS PPCAAAVSRAPEPLATCTQPRKR

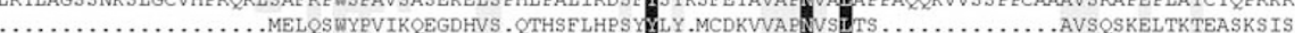

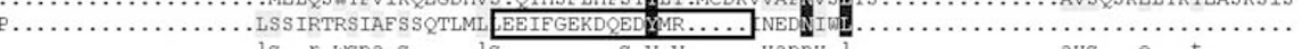
ls r wspa s

avs e t

KLTVDTPGAPETLAPVAAPEEDKDSEAEVEVESREEFTSSLSSLSSPSETSSSSAKDLGS PGARALPSAVPDAAAPADAPSGLEAELEHLRQALEGGLDT RQSEKAHSSGKLOKTVSYPDVSLEEOEKMDLKTSRELCSRLDASISNNSTSKRKSESATCNLVRDINKVGIGLVAAASSP $\ldots \ldots \ldots \ldots$ LLVKDVIC

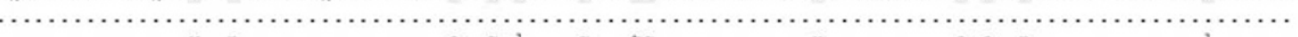
a a p

KEAKEKFLHEVVKMRVKOEEKLSAALOAKRSLHOELEELRVAKKEKLREATEAKRNLRKEIERLRAENEKKMKEANESRLRLKRELEOAROARVCDKGCE EDDKGK IMEEVMRTYLKQQEKLNL ILQKKQQLQMEVKMLSSSK . . SMKELTEEQQNLQKELESLQNEHAQRMEEFYVECKDLEKKLEQIMKQKCTCDSNL

AGRLRAKYSAOIEDLOVKLQHAEADRECLRADLLREREAREHLEKVVKELQEQLWPRARPEAAGSEGAAELE EKDKEAEYAGQLAELRQRLDHAEADRQELODELROEREAROKLEMMIKELKLOILKSSKTAKE $\ldots \ldots \ldots$

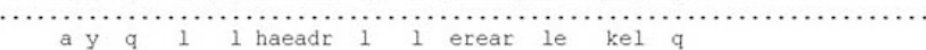

C

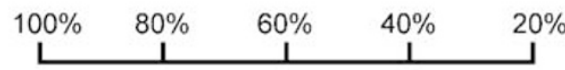

Ski

$37 \%$

Sno

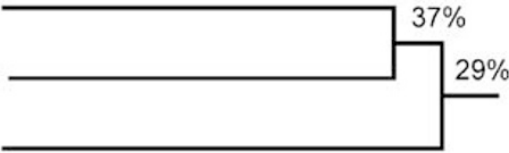

d

C-Ski

C-SnoN

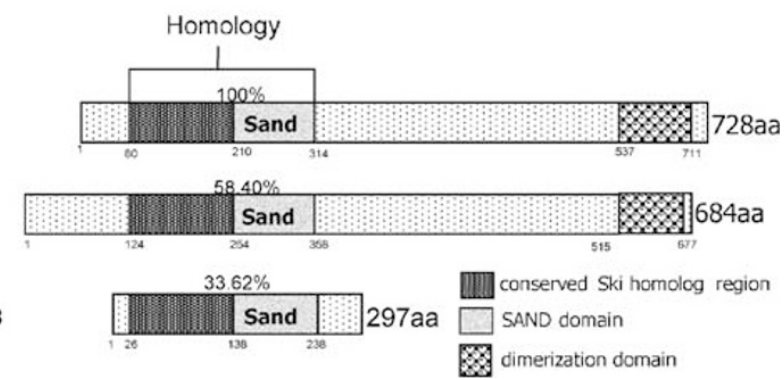

Fussel 18

67 100
19 
The complete cDNA sequence for human fussel18 is shown in Figure 1a. An alignment of the amino-acid sequences of Fussel-18, Ski and Sno is presented in Figure 1b, and displayed schematically as a homology tree in Figure 1c. The Ski family proteins show $29-37 \%$ amino-acid homology.

The calculated molecular mass of Fussel-18 is about $30 \mathrm{kDa}$. A protein alignment between fussel18, Ski and Sno reveals high homology particularly within the SAND domain and the Ski homolog region (Figure 1d). The SAND domain (named after Sp100, AIRE-1, NucP41/75 and DEAF1 ) is an evolutionarily conserved sequence motif found in a number of nuclear proteins that are involved in chromatin-dependent transcriptional regulation.

Table 1 cDNA accession numbers

\begin{tabular}{lll}
\hline Gene & Origin & Accession no. \\
\hline Ski & Human & NM_003036 \\
\multirow{2}{*}{ Sno (ski like) } & Murine & NM_011385 \\
& Human & NM_005414 \\
Fussel-18 & Murine & NM_011386 \\
& Human & AY_669508 \\
& Murine & NT_039675 \\
\hline
\end{tabular}

\section{Expression Patterns of fussel-18 mRNA in Human and Murine Tissues}

To analyze the expression pattern of fussel-18 during embryonic development, in situ hybridizations on murine embryos and PCR studies of embryonic and adult human tissues were performed. Figure 2 shows both, whole mount in situ hybridizations and radioactive in situ hybridizations, on sections from mouse embryos confirming the neuronal-specific expression of fussel-18 during mouse embryogenesis. Fussel-18 is already expressed at E11 in a thin stripe anterior of the fourth ventricle, which will form the future cerebellum (Figure 2a). In addition, strong staining is also observed in the dorsal root ganglia that are located lateral to the neural tube and belong to the peripheral nervous system (Figure $2 \mathrm{~b}$ and $\mathrm{c}$ ). At E13, in addition to these sides of expression, fussel-18 is expressed in the dorsal, sensory part of the spinal cord. Interestingly, although fussel-18 is expressed along the whole neural tube, strongest expression levels are found in the more caudal region (Figure $2 \mathrm{~d}$ and e). Whole mount in situ hybridizations on isolated brains from embryonic stage E15 reveals fussel-18 expression in the primordium of the cerebellum and the spinal cord (Figure $2 \mathrm{f}-\mathrm{h}$ ), whereas no signal is found in other regions of the developing brain. Control hybridizations with a sense cRNA probe revealed no signal

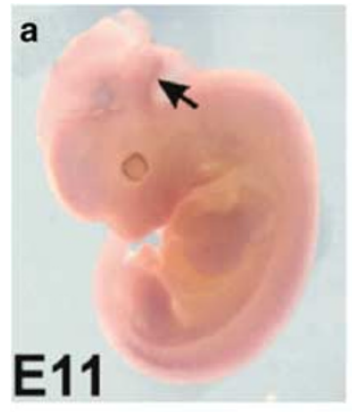

f

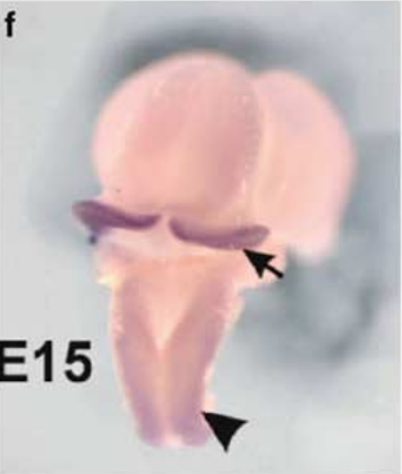

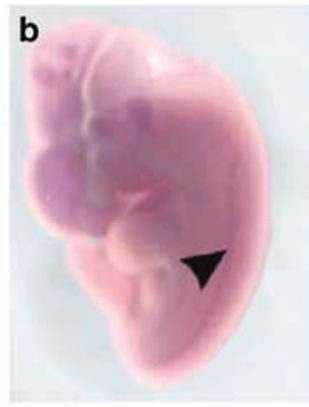
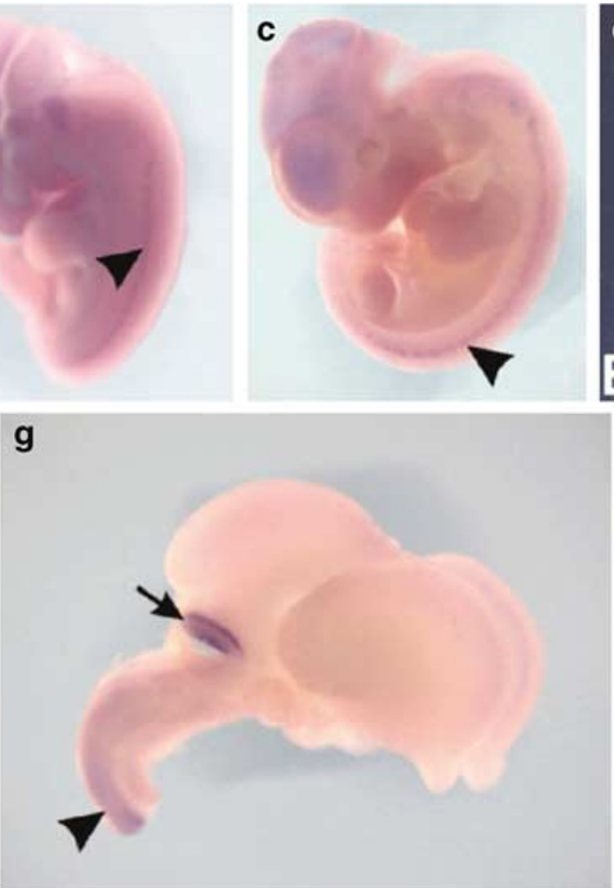
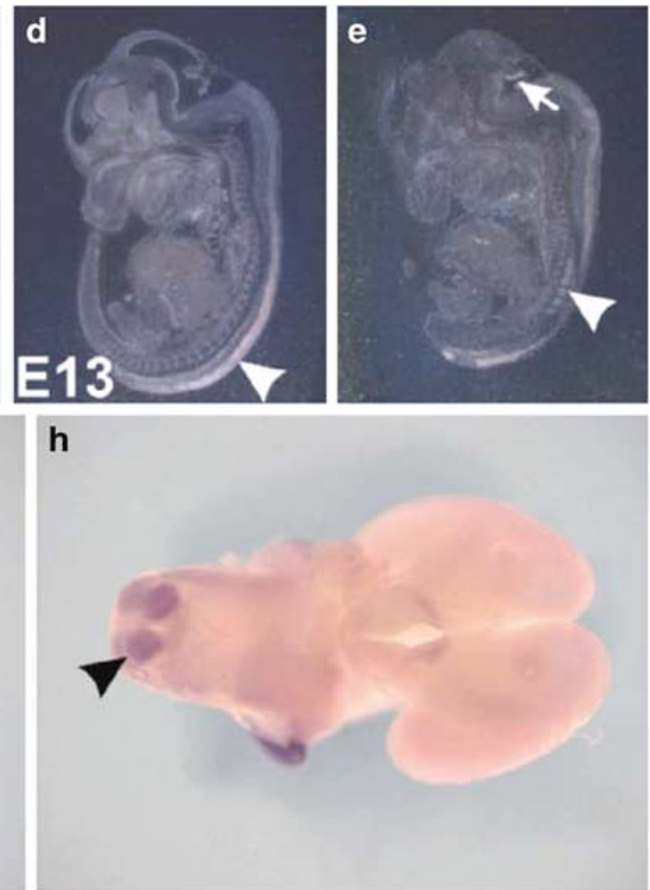

Figure 2 Neuronal expression of fussel-18 during embryogenesis. Whole mount in situ hybridizations of mouse embryos of developmental stages E11 (a-c) and isolated brains from E15 (f-h) together with radioactive in situ hybridizations on sections from E13 (d and e) embryos showing neuronal expression of fussel-18. fussel-18 is specifically expressed in the primordium of the cerebellum at E11, E13 and E15 (arrow in a, e, f and g), in the dorsal root ganglia (arrowheads in b, $\mathbf{c}$ and e), and in the dorsal neural tube with strongest expression in the more caudal region (arrowheads in $\mathbf{d}, \mathbf{f}$ to $\mathbf{h}$ ). 
(data not shown). In comparison, fussel-18 expression was analyzed by RT-PCR in human embryonic and adult tissues by RT-PCR (Figure 3a). All PCR products were sequenced to confirm specificity. In agreement with the results derived from the in situ hybridization on mouse embryos, human fussel-18 revealed a highly specific expression pattern in spinal cord, cerebellum and at very low levels in testis. In contrast, ski and sno are expressed in a variety of tissues. ${ }^{23}$ These data suggest that in contrast to ski and sno that are ubiquitously expressed and probably fulfill a more general cellular function, fussel-18 is supposed to be an important smad regulatory factor of the nervous system which is expressed early in embryogenesis and also in adult tissues.

\section{Expression of Fussel-18 Protein in Human Cerebellum}

To confirm the expression pattern of Fussel-18 also on protein level, we generated a polyclonal antiserum against a c-terminal peptide of the Fussel-18 protein. This peptide shows no homology to the other two members of the ski gene family and is framed in Figure 1b. The antiserum against Fussel18 was characterized in a Western blot using $40 \mu \mathrm{g}$ of human cerebellum protein lysate (Figure $3 \mathrm{~b}$ ). The specificity of the antibody was tested by competing with $5 \mu \mathrm{g} / \mathrm{ml}$ of Fussel-18 c-terminal peptide. Two specific bands were detected about 30 and $60 \mathrm{kDa}$ of Fussel-18 protein.

\section{Fussel-18 is Found in Cerebellar Glomeruli of the Internal Granular Cell Layer (IGL)}

Immunohistochemistry on paraffin-embedded human cerebellum serial sections revealed a punctuate-specific expression pattern of Fussel-18 in cerebellar glomeruli of the IGL (Figure 4a-c). The granular cell layer has a complex architecture. It contains cerebellar glomeruli, which are composed of clusters of granular cell dendrites, mossy fiber terminals and Golgi cell axons. Purkinje cell axons also traverse the granular cell layer. Additionally, few glial cells are localized in the granular cell layer. To determine the cell types expressing Fussel-18 in the cerebellar granular cell layer we used several neuronal and glial markers. The expression pattern of glial fibrillary acidic protein (GFAP), an intermediate filament specific for glial cells, differs from the expression pattern of Fussel-18 ruling out expression of Fussel-18 expression in glial cells (Figure 4d-f). Neurofilaments (NF) are specifically expressed in axons. Colocalization of Fussel-18 with NF was not determined (Figure 4g-i). Synaptophy$\sin$ is an integral membrane glycoprotein that localizes to presynaptic vesicles of neurons. The Fussel-18-staining pattern was highly similar to the staining pattern of Synaptophysin in the IGL suggesting that Fussel-18 is expressed in the non-

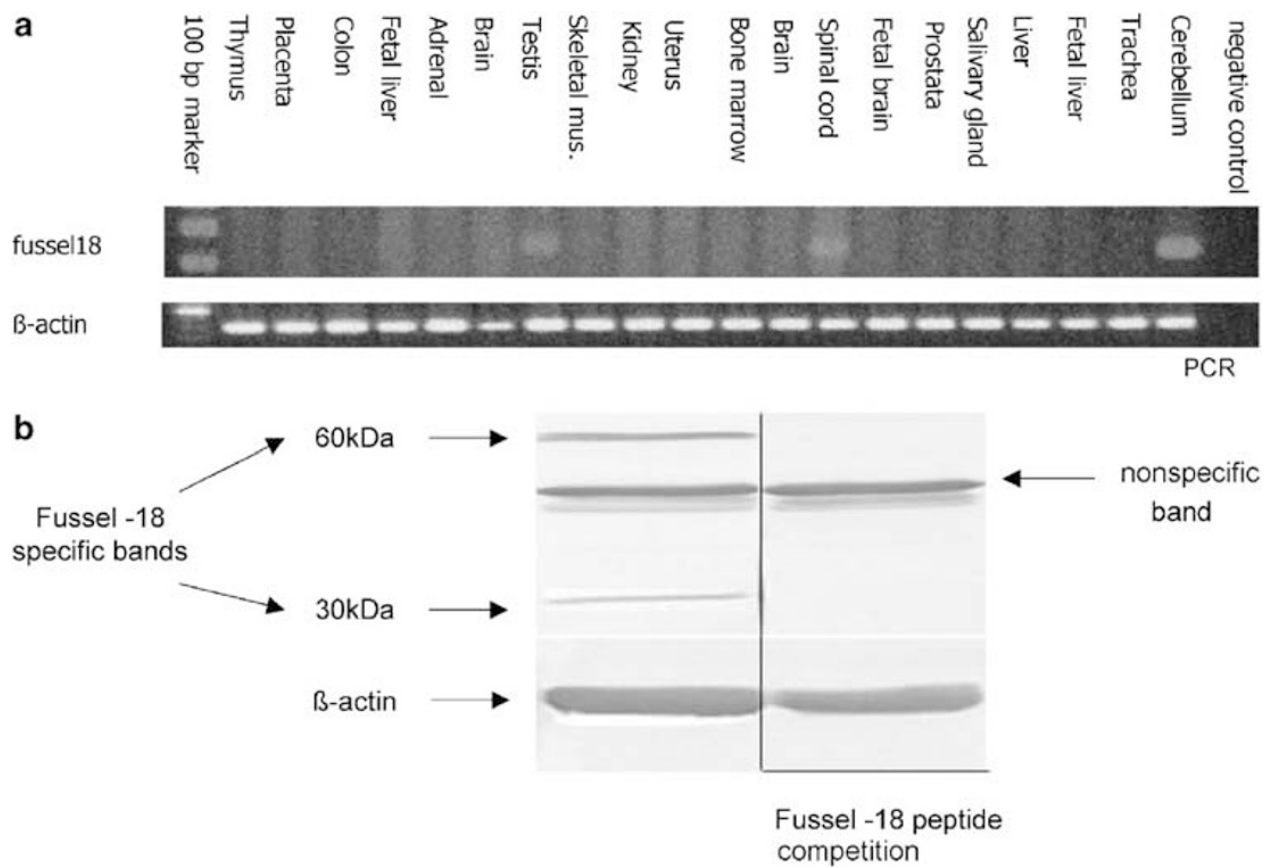

Figure 3 Fussel-18 expression in human tissues. Expression pattern of fussel-18 was verified by semiquantitative PCR from several human tissues. Expression of fussel-18 mRNA was detected in cerebellum and spinal cord and at very low levels in testis. Western blot analysis of Fussel-18 confirmed the expression of Fussel-18 in cerebellum. As a control for the specificity of the antibody we competed the binding of the antibody using $5 \mu \mathrm{g} / \mathrm{ml}$ peptide against Fussel-18. Two specific bands were detected about 30 and $60 \mathrm{kDa}$. 
axonal compartment of the neuronal element of the cerebellar glomerulus (Figure 4j-1). Immunohistochemistry on paraffin-embedded human cerebellum sections showed specific expression of Fussel-18 in cerebellar glomeruli of the IGL (Figure $4 \mathrm{~m}$ ). Figure $4 n$ confirms the specificity of Fussel-18 antibody by
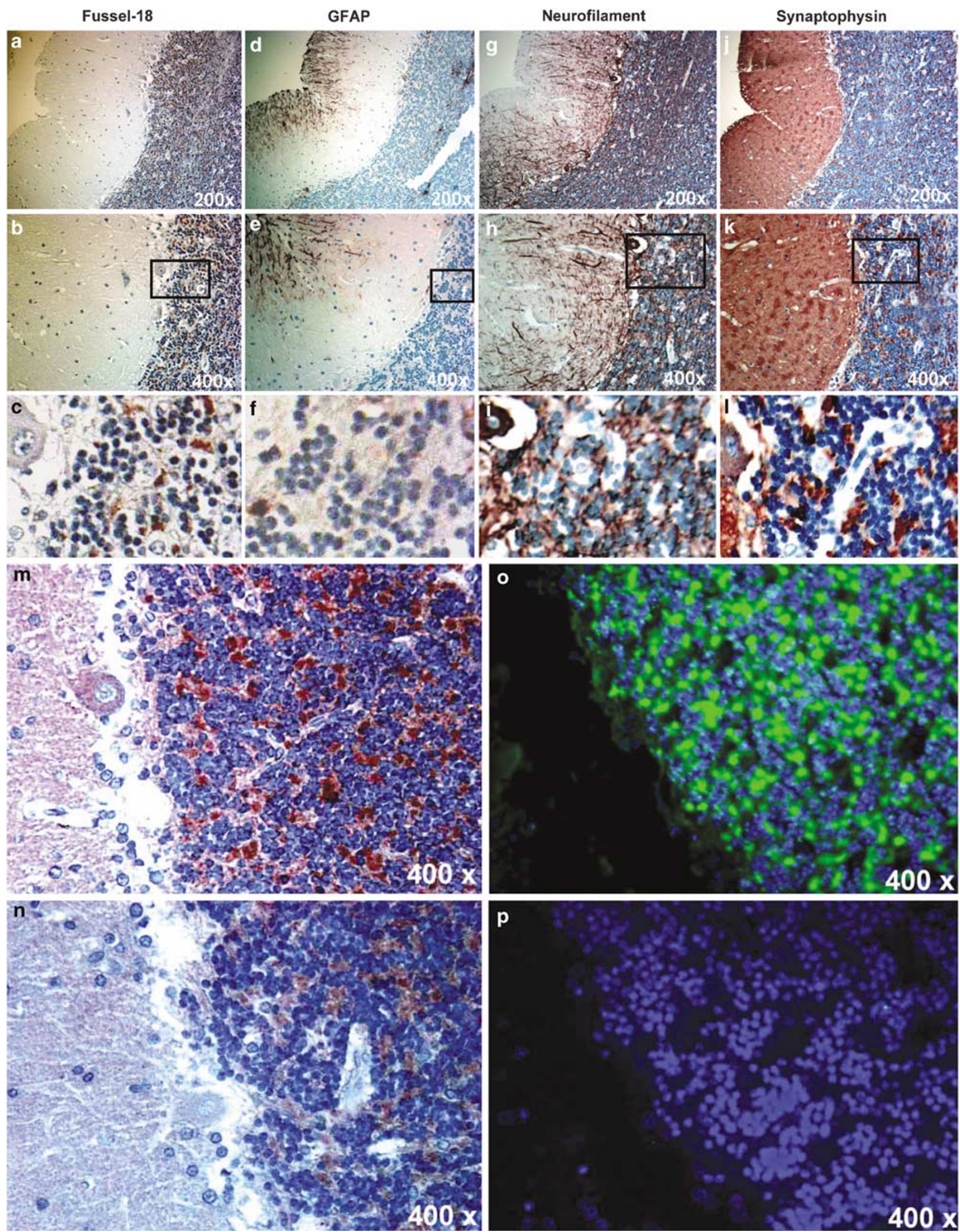
suppression of antibody binding with Fussel-18derived peptide.

Immunofluorescence on paraffin-embedded cerebellum sections confirms the specific expression pattern of Fussel-18 (Figure 40). The suppression of Fussel-18 antibody binding by peptide blockade is shown in Figure 4p.

\section{Immunofluorescence on Cells of the Nervous System Detected Cytoplasmic and Nuclear Staining of Fussel-18}

Immunofluorescence observations on HTZ-17 glioblastoma cell line revealed staining of Fussel-18 in the cytoplasm, and in the nucleus (Figure 5a/b). As control for the specificity of the antibody we incubated the cells without primary Fussel-18 antibody (Figure 5c).To confirm the cytoplasmic and nuclear localization of Fussel-18, we performed cell fractionation. We transfected 293T cells, which not express Fussel-18, with pCMX-PL2-Flag-Fussel-18. Afterwards we isolated the cytoplasmic-, nuclearand membrane fractions of the cells. Western blot analysis with anti-Flag antibody detected high expression of Fussel-18 mainly in the nucleus; however, small amount of Fussel-18 were detectable in the cytoplasm (Figure 6).

\section{Several Genes of the TGF- $\beta$ and Bone Morphogenetic Protein (BMP) Pathways are Expressed in Cerebellum}

While it is tempting to speculate that in analogy to Ski and Sno, Fussel-18 is involved in TGF- $\beta$ - or BMP-signaling pathways, we were interested if single molecules of these pathways are expressed in cerebellum and could be potential interacting partners of Fussel-18. RT-PCR with human adult cerebellum cDNA revealed expression of Smad1-7, TGF- $\beta 1-3$, BMP R1A/B, BMP R1B, BMP2/7 and Bambi in cerebellum (Figure 7) suggesting an important role of the TGF- $\beta$ /BMP pathways also in nervous tissues.

\section{Fussel-18 Directly Interacts with Smad2 and Smad3}

In analogy to Ski and Sno we speculate that Fussel18 binds to Smad proteins. To this end, we performed co-immunoprecipitations to analyze a possible interaction between Fussel-18 and Smad proteins. To enhance the binding of the two proteins
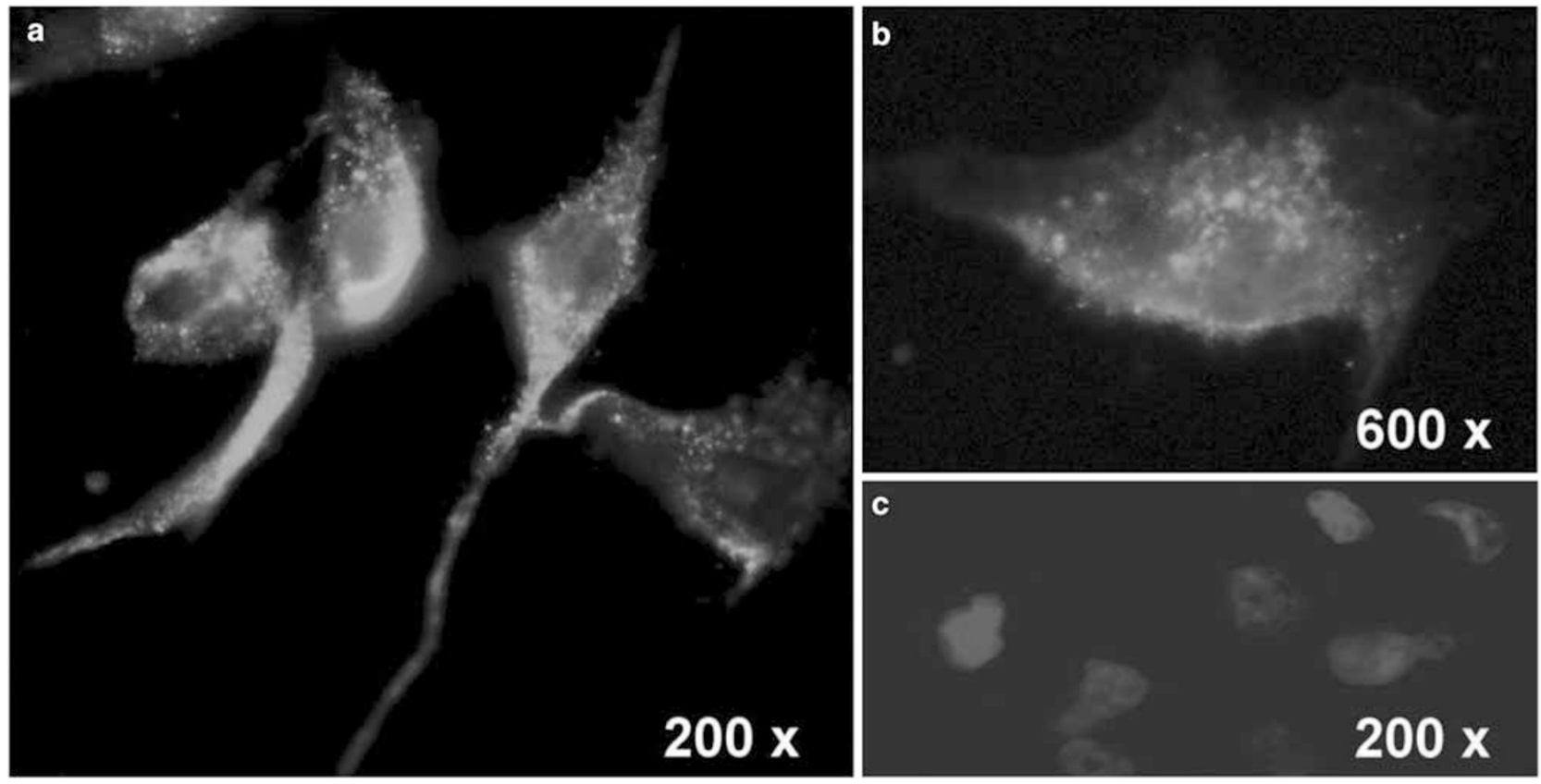

Figure 5 Immunofluorescence on cells of the nervous system detected cytoplasmic and nuclear staining of Fussel-18. (a/b) Immunofluorescence staining of glioblastoma cells revealed staining of Fussel-18 in the cytoplasm, and in the nucleus (different magnifications). (c) As control for the specificity of the antibody we incubated the cells without primary Fussel-18 antibody.

Figure 4 Histological analysis of Fussel-18 expression in cerebellum sections. (a-c) Immunohistology on paraffin-embedded cerebellum serial sections showed specific expression of Fussel-18 in cerebellar glomeruli of the internal granular cell layer (IGL) (different magnifications). (d-f) The expression pattern of GFAP differs from the expression pattern of Fussel-18. (g-i) The expression pattern of neurofilament (NF) in the internal granular cell layer differs from the expression pattern of Fussel-18. (j-l) The expression of Synaptophysin is colocalized with Fussel-18 in neural elements of the granular cell layer. (m/n) The specificity of Fussel-18 antibody was confirmed by suppression of antibody binding with Fussel-18-derived peptide (n). (o/p) Immunofluorescence staining of Fussel-18 in cerebellum sections confirmed the specific expression of this protein in cerebellar glomeruli of the internal granular cell layer (IGL) (o). The specificity of Fussel-18 antibody was confirmed by suppression of antibody binding with Fussel-18-derived peptide (p). 


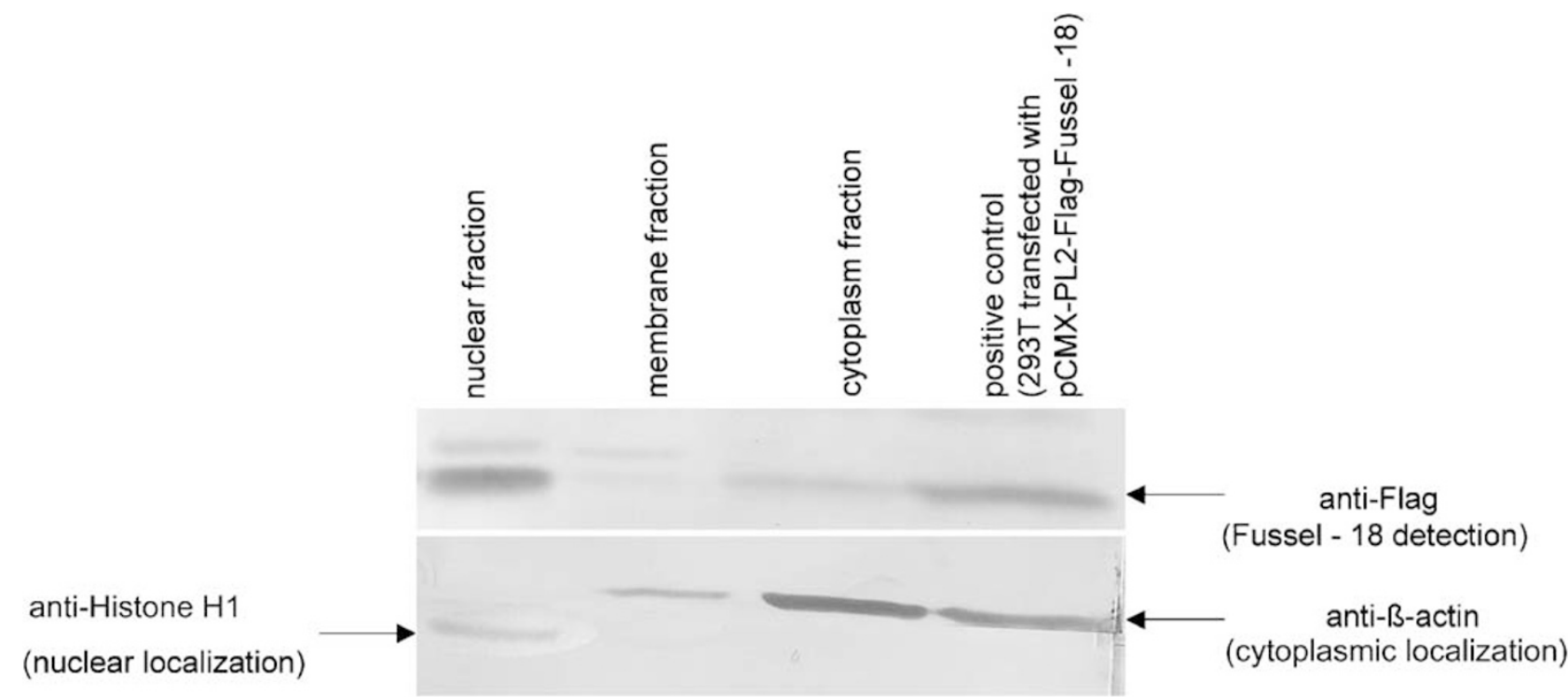

Figure 6 Cell fractionation confirmed the cytoplasmatic and nuclear localization of Fussel-18. 293T cells, which not express Fussel-18, were transfected with pCMX-PL2-Flag-Fussel-18. Cytoplasm, nucleus and membrane fractions were isolated from the cells. Western blot analysis with anti-Flag antibody detected high expression of Fussel-18 mainly in the nucleus, however small amount of Fussel -18 were detectable in the cytoplasm. For specificity of the fractionation we used anti- $\beta$-actin and anti-Histon H1 antibody (specific for nuclear localization).

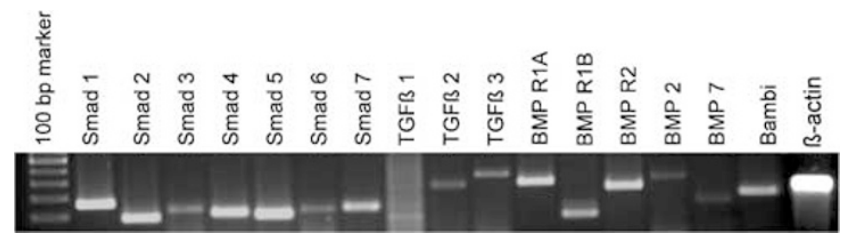

Figure 7 Several genes of the TGF- $\beta$ and BMP pathways are expressed in cerebellum. RT-PCR revealed expression of Smad17, TGF- $\beta 1-3$, BMP R1A/B, BMP R1B, BMP2/7 and Bambi in human adult cerebellum.

we cotransfected Mel Im melanoma cells, which not express Fussel-18, with pCMX-PL2-Flag-fussel-18 and Smad2 or Smad3, respectively, and for control experiments with pCDNA3-Flag-ski. Figure 8b/c demonstrates the interaction of Fussel-18 with Smad2 and Smad3. Consistent with the published observations ${ }^{9}$ interaction of Ski with Smad2 and Smad3 is found.

\section{Fussel-18 Represses TGF- $\beta$ Signaling}

Ski has been reported to bind in a Smad-dependent manner to the Smad-binding element that contains a CAGA sequence. ${ }^{9}$ To investigate the functional activity of Fussel-18 on TGF- $\beta$ signaling, we performed luciferase reporter assays. We examined the influence of Fussel-18 on TGF- $\beta$ signaling by treating the ski-, fussel-18- or mock-transfected $293 \mathrm{~T}$ cells with TGF- $\beta 3$. As shown in Figure 9, Fussel-18 inhibited the activation of (CAGA) $)^{-}$ Luc after TGF- $\beta 3$ stimulation about four-fold and consistent with the previous observations ${ }^{9}$ the activation of (CAGA) $)_{9}$-Luc induced by TGF- $\beta$ was inhibited in ski-transfected cells.

\section{Discussion}

We identified the novel human gene fussel-18 as a new member of the ski/sno family of transcriptional corepressors. Furthermore, we analyzed the expression pattern of fussel-18 on mRNA and protein level. In contrast to the broad expression pattern of Ski and Sno, Fussel-18 is specifically expressed in the nervous system suggesting that this protein has an important function. In vertebrates, Ski and Sno antagonize TGF- $\beta$ signaling by binding to Smads. Our analyses also demonstrate that the novel protein Fussel-18 binds directly to Smad2 and Smad3 and represses TGF- $\beta$ signaling. Therefore, we named this protein 'functional Smad suppressing element on chromosome 18'. The fussel-18 gene is localized on chromosome 18. The protein is localized mainly in the nucleus of cells of the nervous system. Histological analysis confirmed a punctuate expression pattern of Fussel-18 specifically in the cerebellar glomerulus of the granular cell layer. A cerebellar glomerulus is a complex of synapses having a mossy fiber ending (rosette) as its core, synapsing with axons of Golgi neurons and dendrites of granular cells. Mossy fibers are the main afferent input to the granular cell layer of the cerebellar cortex. They orginate from a multitude of areas in the brainstem and spinal cord and terminate within the granular cell layer. ${ }^{24}$ Whole mount in situ hybridizations on isolated brains from embryonic stage E15 reveals Fussel-18 expression in the primordium of the 

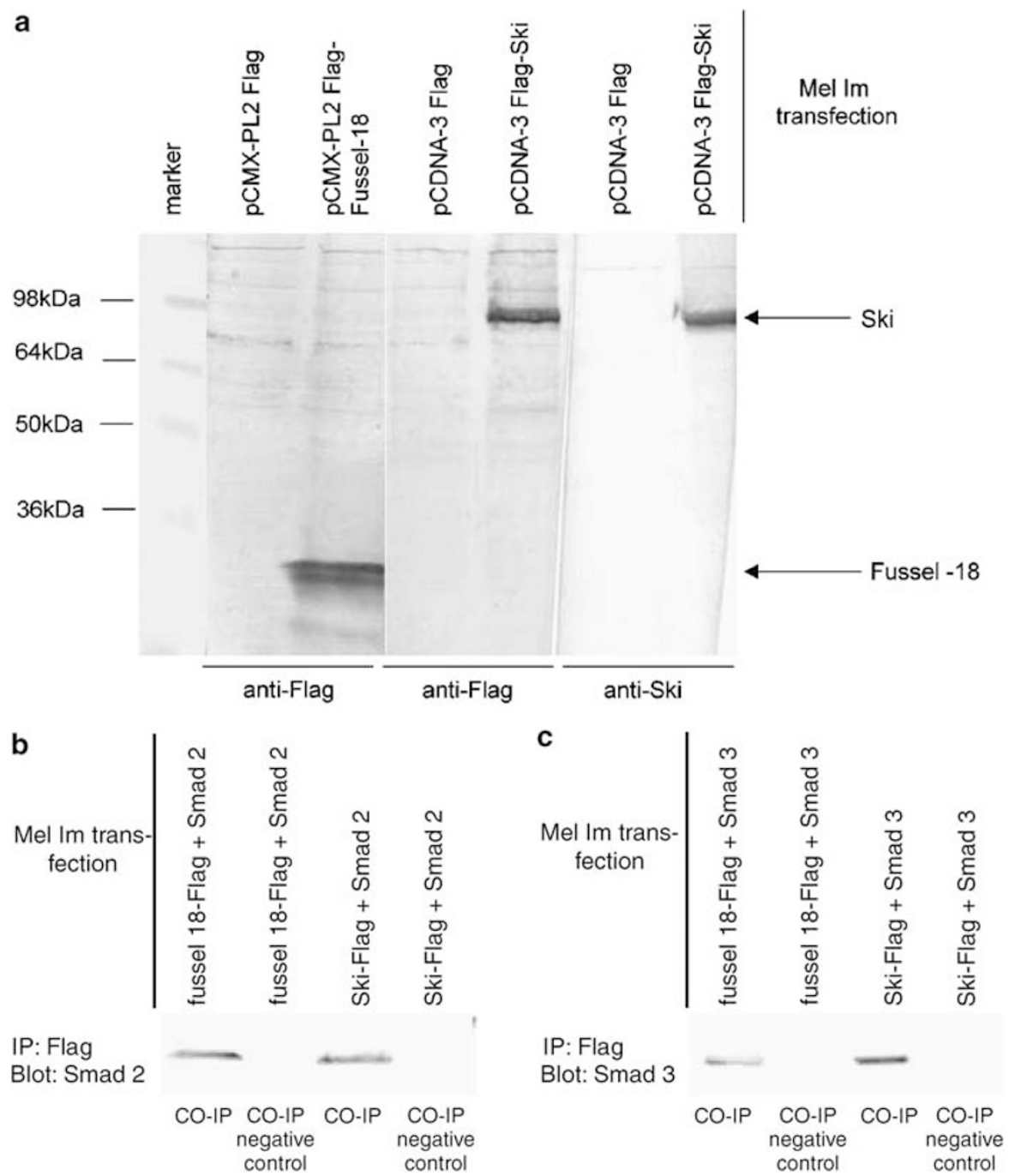

Figure 8 Transfection and interaction of Fussel-18 and Ski with Smad proteins. (a) Transfection control experiment. Mel Im cells were transfected with different plasmids (Flag-coupled-ski and -fussel-18 vectors and Flag-coupled control vectors). The efficiency of the transfection was detected by Western blotting using specific antibodies (anti-ski, anti-Flag). (b/c) Co-immunoprecipitation (Co-IP) revealed an interaction of Fussel-18 with Smad2 (b) and Smad3 (c). Co-immunoprecipitation was utilized to show direct interaction of Fussel-18 with Smad proteins. For immunoprecipitation (IP) anti-Flag-antibody was used. Interaction was detected using Western blot analysis with Smad2 and Smad3 antibody.

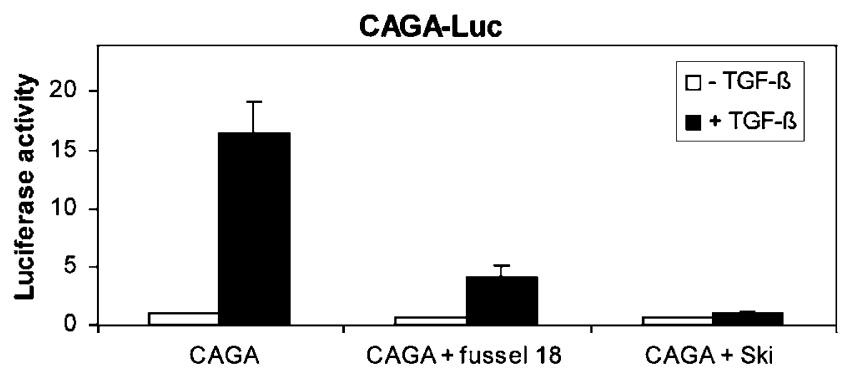

Figure 9 Fussel-18 represses TGF- $\beta$ signaling. To investigate the functional activity of Fussel-18 on TGF- $\beta$ signaling, we performed luciferase reporter assays. We examined the influence of Fussel18 on TGF- $\beta$ signaling by treatment of fussel-18-transfected 293T cells with TGF- $\beta 3$. Fussel-18 inhibited the activation of (CAGA) ${ }_{9}-$ Luc after TGF- $\beta 3$ stimulation and consistent with the previous observations, ${ }^{9}$ the activation of (CAGA) $)_{9}$-Luc induced by TGF- $\beta$ was inhibited in ski-transfected cells. cerebellum and the spinal cord (Figure 2f-h). We suggest that this early expression of Fussel-18 in the spinal cord may correlate with the emergence of the mossy fibers. Each mossy fiber branches profusely in the white matter. Each of this branches has multiple (up to 50) swellings that contain round vesicles and synaptic thickenings. Each swelling, called a 'rosette' is a synapse of the mossy fiber with the dendrite of a granular cell. We suggest that the punctuate Fussel18 expression on paraffin-embedded cerebellum sections (Figure 4a-c) may correlate with the mossy fiber 'rosettes'. Further staining and experiments must proof this hypothesis.

Fussel-18 is the only known example of the Ski/ Sno family acting as a TGF- $\beta$ antagonist specifically in the nervous system. 
Da Graca et $a l^{25}$ reported that the C. elegans protein Daf-5, a Ski homolog that functions also in neuronal TGF- $\beta$ pathways to regulate $C$. elegans dauer development. It might be possible that Fussel18 also plays important roles during vertebrate development. We could demonstrate that in early stages of mouse embryogenesis fussel-18 is already expressed in areas of the neuronal system.

We have further shown that several genes of the TGF- $\beta$ and BMP pathways are expressed in cerebellum (Figure 7). The TGF- $\beta$ superfamily consists of several subfamilies with more than 40 ligands. ${ }^{26}$ The TGF- $\beta$ subfamily has three members: TGF- $\beta 1, \beta 2$ and $\beta 3$. In the brain, TGF- $\beta 1$ is expressed mainly in the meninges. ${ }^{27,28}$ During early development, TGF- $\beta 2$ and $\beta 3$ are widely expressed in the central nervous system (CNS). ${ }^{29}$ However, their expression is generally not associated with areas enriched with dividing progenitor cells, suggesting that TGF- $\beta$ s are not involved in controlling mitosis in the CNS (except in cerebellar granular neurons of external granular cell layer). ${ }^{28}$ In the adult brain, TGF- $\beta 2$ is found in astrocytes as well as in large neurons and cerebellar Purkinje neurons. ${ }^{30}$ TGF- $\beta 3$ is widely distributed throughout the postnatal brains although at very low levels. ${ }^{27,28}$ In the cerebellum, TGF- $\beta 2$ is the predominant isoform produced by Purkinje cells and by both proliferating and postmitotic granular cells. ${ }^{31}$ TGF- $\beta 2$ regulates the proliferation of cultured cerebellar neurons. ${ }^{31,32}$ Additionally, it is published that BMPs and their receptors are also expressed in brain. ${ }^{33}$ However, very little is known about the expression and distribution of Smad proteins in the brain. Even less is known about the role of Smads in the development and function of the brain. Therefore, currently it is difficult to speculate about possible functions of Fussel-18.

In summary, we show that Fussel-18 is predominantly expressed in the cerebellum and acts as a new inhibitor of TGF- $\beta$ signaling. This new protein binds directly to Smad2 and Smad3 and expanded the family of Ski/Sno proto-oncoproteins.

\section{Acknowledgements}

We are indebted to Susanne Wallner, Sibylla Lodermeyer and Petra Weiderer for technical assistance. The work was supported by the DFG.

\section{References}

1 Heldin $\mathrm{CH}$, Miyazono $\mathrm{K}$, ten Dijke P. TGF-beta signalling from cell membrane to nucleus through SMAD proteins. Nature 1997;390:465-471.

2 Elliott RL, Blobe GC. Role of transforming growth factor Beta in human cancer. J Clin Oncol 2005;23: 2078-2093.

3 Liu F, Hata A, Baker JC, et al. A human Mad protein acting as a BMP-regulated transcriptional activator. Nature 1996;381:620-623.
4 Zhang Y, Musci T, Derynck R. The tumor suppressor Smad4/DPC 4 as a central mediator of Smad function. Curr Biol 1997;7:270-276.

5 Liu X, Sun Y, Weinberg RA, et al. Ski/Sno and TGF-beta signaling. Cytokine Growth Factor Rev 2001; 12:1-8.

6 Chen Y, Bhushan A, Vale W. Smad8 mediates the signaling of the ALK-2 [corrected] receptor serine kinase. Proc Natl Acad Sci USA 1997;94:1293812943.

7 Fumagalli S, Doneda L, Nomura N, et al. Expression of the c-ski proto-oncogene in human melanoma cell lines. Melanoma Res 1993;3:23-27.

8 Nomura N, Sasamoto S, Ishii S, et al. Isolation of human cDNA clones of ski and the ski-related gene, sno. Nucl Acids Res 1989;17:5489-5500.

9 Akiyoshi S, Inoue H, Hanai J, et al. c-Ski acts as a transcriptional co-repressor in transforming growth factor-beta signaling through interaction with smads. J Biol Chem 1999;274:35269-35277.

10 Luo K, Stroschein SL, Wang W, et al. The Ski oncoprotein interacts with the Smad proteins to repress TGFbeta signaling. Genes Dev 1999;13:21962206.

11 Stroschein SL, Wang W, Zhou S, et al. Negative feedback regulation of TGF-beta signaling by the SnoN oncoprotein. Science 1999;286:771-774.

$12 \mathrm{Xu} \mathrm{W}$, Angelis K, Danielpour D, et al. Ski acts as a co-repressor with Smad2 and Smad3 to regulate the response to type beta transforming growth factor. Proc Natl Acad Sci USA 2000;97:5924-5929.

13 Nicol R, Stavnezer E. Transcriptional repression by v-Ski and c-Ski mediated by a specific DNA binding site. J Biol Chem 1998;273:3588-3597.

14 Frederick JP, Wang XF. Smads 'freeze' when they ski. Structure (Camb ) 2002;10:1607-1611.

15 Qin BY, Lam SS, Correia JJ, et al. Smad3 allostery links TGF-beta receptor kinase activation to transcriptional control. Genes Dev 2002;16:1950-1963.

16 Mizuide M, Hara T, Furuya T, et al. Two short segments of Smad3 are important for specific interaction of Smad3 with c-Ski and SnoN. J Biol Chem 2003; 278:531-536.

17 Ueki N, Hayman MJ. Direct interaction of Ski with either Smad3 or Smad4 is necessary and sufficient for Ski-mediated repression of transforming growth factor-beta signaling. J Biol Chem 2003;278: 32489-32492.

18 Ueki N, Hayman MJ. Signal-dependent N-CoR requirement for repression by the Ski oncoprotein. J Biol Chem 2003;278:24858-24864.

$19 \mathrm{Wu}$ JW, Krawitz AR, Chai J, et al. Structural mechanism of Smad4 recognition by the nuclear oncoprotein Ski: insights on Ski-mediated repression of TGF-beta signaling. Cell 2002;111:357-367.

20 Prunier C, Pessah M, Ferrand N, et al. The oncoprotein Ski acts as an antagonist of transforming growth factorbeta signaling by suppressing Smad2 phosphorylation. J Biol Chem 2003;278:26249-26257.

21 Wilkinson DG, Nieto MA. Detection of messenger RNA by in situ hybridization to tissue sections and whole mounts. Methods Enzymol 1993;225:361-373.

22 Moser M, Imhof A, Pscherer A, et al. Cloning and characterization of a second AP-2 transcription factor: AP-2 beta. Development 1995;121:2779-2788.

23 Luo K. Ski and SnoN: negative regulators of TGF-beta signaling. Curr Opin Genet Dev 2004;14:65-70. 
24 Ruigrok TJ. Collateralization of climbing and mossy fibers projecting to the nodulus and flocculus of the rat cerebellum. J Comp Neurol 2003;466:278-298.

25 da Graca LS, Zimmerman KK, Mitchell MC, et al. DAF-5 is a Ski oncoprotein homolog that functions in a neuronal TGF beta pathway to regulate C. elegans dauer development. Development 2004;131: 435-446.

26 Massague J. TGF-beta signal transduction. Annu Rev Biochem 1998;67:753-791.

27 Unsicker K, Strelau J. Functions of transforming growth factor-beta isoforms in the nervous system. Cues based on localization and experimental in vitro and in vivo evidence. Eur J Biochem 2000;267:69726975.

28 Bottner M, Krieglstein K, Unsicker K. The transforming growth factor-betas: structure, signaling, and roles in nervous system development and functions. J Neurochem 2000;75:2227-2240.
29 Flanders KC, Ludecke G, Engels S, et al. Localization and actions of transforming growth factor-beta $s$ in the embryonic nervous system. Development 1991;113: 183-191.

30 Unsicker K, Flanders KC, Cissel DS, et al. Transforming growth factor beta isoforms in the adult rat central and peripheral nervous system. Neuroscience 1991;44: 613-625.

31 Constam DB, Schmid P, Aguzzi A, et al. Transient production of TGF-beta 2 by postnatal cerebellar neurons and its effect on neuroblast proliferation. Eur J Neurosci 1994;6:766-778.

32 Kane CJ, Brown GJ, Phelan KD. Transforming growth factor-beta 2 both stimulates and inhibits neurogenesis of rat cerebellar granule cells in culture. Brain Res Dev Brain Res 1996;96:46-51.

33 Ebendal T, Bengtsson H, Soderstrom S. Bone morphogenetic proteins and their receptors: potential functions in the brain. J Neurosci Res 1998;51:139-146. 